\title{
Endometriosis and Ovarian Cancer: A Systematic Review
}

\author{
Ahmad Sayasneh, Dimitris Tsivos, and Robin Crawford \\ Department of Obstetrics \& Gynaecology, The Rosie Hospital, Cambridge University Hospital NHS Trust, \\ Hills Road, Cambridge CB2 2QQ, UK
}

Correspondence should be addressed to Ahmad Sayasneh, sayasneh@gmail.com

Received 1 April 2011; Accepted 21 May 2011

Academic Editors: J. M. Goldberg, R. Kimmig, and W. Yeung

Copyright ( $) 2011$ Ahmad Sayasneh et al. This is an open access article distributed under the Creative Commons Attribution License, which permits unrestricted use, distribution, and reproduction in any medium, provided the original work is properly cited.

\begin{abstract}
Introduction. Endometriosis is one of the most common benign disorders which affects $10-15 \%$ of all women in reproductive age. The association between endometriosis and ovarian cancer has been frequently described in the medical literature. Purpose. To evaluate the literature for evidence of a correlation between endometriosis and ovarian cancer. Method. the English language literature (online MEDLINE and EMBASE database) was searched using the keywords endometriosis combined with cancer, tumour, tumor, carcinoma, or adenocarcinoma. All abstracts between January 1985 and August 2010 were reviewed. Full relevant articles were critically assessed. Reference lists of included studies were checked. Results. Seven out of the eight studies, included in our review, have shown an increased risk of ovarian cancer. However, the effect size is modest (OR, RR, and SIR) ranging between 1.32 and 1.9 (95\% CI). A causative relationship between the two incidences cannot be confirmed. There is increasing evidence on the role of genetic mutations in ovarian clear-cell and endometrioid carcinoma developing from endometriosis. Conclusion. More evidence is needed before suggesting any change in the current management of endometriosis.
\end{abstract}

\section{Introduction}

Endometriosis is one of the most common gynaecological disorders. It affects $10-15 \%$ of all women in the reproductive years [1]. The incidence is $40-60 \%$ in women with dysmenorrhoea and $20-30 \%$ in those with subfertility [1]. Although endometriosis is recognised as a benign disease, its association with ovarian cancer has been frequently described in the medical literature since 1925. In that year, Sampson established the first histopathological criteria, which are still in use, to identify malignant tumours rising from endometriosis: (1) clear evidence of endometriosis close to the tumour, (2) the carcinoma must be seen to arise in endometriosis, and not to be invading it from other sources, and (3) presence of tissue resembling endometrial stroma surrounding characteristic glands [2]. Later in 1953, Scott has added a fourth criterion which is the demonstration of a histology-proven transition from benign endometriosis to cancer [3]. The application of all these four criteria has rarely been fulfilled in the literature, which supports the idea that the malignant transformation of endometriosis is a rare event [4]. Yet, their stringent use may lead to underestimate the real frequency of this phenomenon [4].
The aim of this paper is to systematically review the literature evidence of a correlation between endometriosis and ovarian cancer.

\section{Methods}

A protocol-driven systematic review was conducted in accordance with the Centre for Reviews and Dissemination (CRD) guidance. [5] The English language literature (online MEDLINE and EMBASE database) was searched using the keywords: endometriosis combined with cancer, tumour, tumor, carcinoma, or adenocarcinoma. All abstracts between January 1985 and August 2010 were reviewed and full articles of relevant publications in English language were retrieved. A further systematic analysis of the publications included in the reference lists was performed. All up-to-date reviews on the same topic in the literature were assessed according to Glasgow appraisal tool [6]. Case reports and case series studies were excluded from our review.

\section{Results}

Seven reviews were found in the literature [4, 7-12], which have addressed the association between endometriosis and 
TABLe 1: A summery of the reviews' findings.

\begin{tabular}{|c|c|c|c|c|c|}
\hline Review & $\begin{array}{c}\text { Language of } \\
\text { literature } \\
\text { searched }\end{array}$ & Type of studies included & $\begin{array}{l}\text { Quality assessment } \\
\text { tool used in the } \\
\text { review }\end{array}$ & Overall results & Application of results \\
\hline $\begin{array}{l}\text { Ness } 2003 \\
{[7]}\end{array}$ & English & $\begin{array}{l}\text { In vitro, animal, clinical, } \\
\text { and epidemiologic } \\
\text { studies }\end{array}$ & Not specified & $\begin{array}{l}\text { Consistent with the association } \\
\text { between endometriosis and } \\
\text { ovarian cancer. }\end{array}$ & $\begin{array}{l}\text { Possible chemoprevention for } \\
\text { women with endometriosis. }\end{array}$ \\
\hline $\begin{array}{l}\text { Somigliana } \\
\text { et al. } 2006 \\
{[4]}\end{array}$ & English & $\begin{array}{l}\text { Observational, cohort, } \\
\text { and case-control }\end{array}$ & $\begin{array}{l}\text { Studies have been } \\
\text { critically analysed. }\end{array}$ & $\begin{array}{l}\text { Increased risk of ovarian cancers: } \\
\text { effect size: } 1.3-1.9 \text {. }\end{array}$ & $\begin{array}{l}\text { Modifications of the standard } \\
\text { treatment options for the } \\
\text { disease are not justifiable. }\end{array}$ \\
\hline $\begin{array}{l}\text { Vigano et } \\
\text { al. } 2007 \\
{[8]}\end{array}$ & English & $\begin{array}{l}\text { Observational, cohort, } \\
\text { and case-control } \\
\text { epidemiologic, } \\
\text { biological, and genetic } \\
\text { studies }\end{array}$ & $\begin{array}{l}\text { Nineriteria, by } \\
\text { Austin Bradford } \\
\text { Hill [13] }\end{array}$ & $\begin{array}{l}\text { The criterion of strength has not } \\
\text { been fulfilled. There were } \\
\text { insufficient data for four criteria, } \\
\text { and four criteria were fulfilled. }\end{array}$ & $\begin{array}{l}\text { The low magnitude of the risk } \\
\text { observed is consistent with the } \\
\text { view that ectopic } \\
\text { endometrium undergoes } \\
\text { malignant transformation } \\
\text { with a frequency similar to its } \\
\text { eutopic counterpart. }\end{array}$ \\
\hline $\begin{array}{l}\text { Nezhat et } \\
\text { al. } 2008 \\
\text { [9] }\end{array}$ & English & $\begin{array}{l}\text { Observational, cohort, } \\
\text { and case-control } \\
\text { epidemiologic, } \\
\text { histopathological, and } \\
\text { molecular studies }\end{array}$ & Not specified & $\begin{array}{l}\text { Histological transition from } \\
\text { benign endometriosis to ovarian } \\
\text { malignancy. }\end{array}$ & $\begin{array}{l}\text { The malignant potential of } \\
\text { endometriosis holds serious } \\
\text { implications for management. }\end{array}$ \\
\hline $\begin{array}{l}\text { Baldi et al. } \\
2008[10]\end{array}$ & English & Not specified & Not specified & $\begin{array}{l}\text { Further epidemiological and } \\
\text { genetic studies are required. }\end{array}$ & $\begin{array}{l}\text { Appropriate physical } \\
\text { screening and imaging testing } \\
\text { are recommended. }\end{array}$ \\
\hline $\begin{array}{l}\text { Vlahos et } \\
\text { al. } 2010 \\
{[11]}\end{array}$ & $\begin{array}{l}\text { No search } \\
\text { criteria } \\
\text { specified }\end{array}$ & $\begin{array}{l}\text { No search criteria } \\
\text { specified }\end{array}$ & Not specified & $\begin{array}{l}\text { Endometriosis is associated with } \\
\text { specific types of ovarian cancer } \\
\text { (endometrioid and clear cell). }\end{array}$ & $\begin{array}{l}\text { More studies are needed to } \\
\text { establish the risk factors that } \\
\text { may lead to malignant } \\
\text { transformation. }\end{array}$ \\
\hline $\begin{array}{l}\text { Kobayashi } \\
2010[12]\end{array}$ & English & $\begin{array}{l}\text { Studies on screening, } \\
\text { epidemiology, clinical } \\
\text { diagnosis, natural } \\
\text { history, preclinical and } \\
\text { clinical trials, and } \\
\text { promising molecular } \\
\text { targets on epithelial } \\
\text { ovarian cancer (EOC). }\end{array}$ & Not specified & $\begin{array}{l}\text { Ovarian endometrioma could be } \\
\text { viewed as a neoplastic process. }\end{array}$ & $\begin{array}{l}\text { Understanding the } \\
\text { mechanisms of endometriosis } \\
\text { development and elucidating } \\
\text { its pathogenesis and } \\
\text { pathophysiology are intrinsic } \\
\text { to prevention. }\end{array}$ \\
\hline
\end{tabular}

ovarian cancer. A summarizing table of the reviews' findings was modified from the Glasgow appraisal tool (Table 1) [6].

In our review, 11 studies were identified, which addressed the association between endometriosis and ovarian cancer [14-24]. To remove the selection bias, studies on the $s u b$ fertility patients with endometriosis $[14,15]$ and studies on endometriomas instead of endometriosis [16] were excluded. Eight studies were included in the list [17-24]. Seven out of the eight studies have shown an increased risk of ovarian cancer. However, the effect size is modest (odd ratio OR, relative risk $R R$, and standardized incidence ratio SIR), ranging between 1.32 and 1.9 (95\% CI) Figure 1.

In epidemiological terms, when the RR is less than 2 , a careful assessment of the confounding factors must be conducted before any conclusion of causality can be made [25, 26]. The previous epidemiologic definition was considered when we selected the studies. Table 2 summarises the types, sample size, followup time, confounding factors, and limitation of each one of the eight studies included in our review.

\section{Discussion}

Despite the studies presented, the risk of ovarian cancer among patients with endometriosis has always been contentious. Endometriosis is usually confirmed by laparoscopic or histological examination, and many patients are unaware of having the disorder. Therefore, identifying endometriosis as a preceding factor of ovarian cancer is not possible in many cases. On the other hand, the natural history of ovarian cancer is not well understood and the origin of the precursor cell, especially for endometrioid and clear-cell variants, is questionable. For these reasons, all studies in the literature would struggle to establish a causal relationship between the two entities. In this updated review we have tried to assess the epidemiologic evidence in the literature and to discuss our findings in view of the other genetic, immunological, and biological relevant studies.

In our review we have found another group of eight epidemiologic studies that correlated endometriosis with 
TABle 2: Summary the types, sample size, followup time, confounding factors, and limitation of each one of the eight studies included in our review.

\begin{tabular}{|c|c|c|c|c|c|c|}
\hline Name of study & Type & $\begin{array}{l}\text { Mean of } \\
\text { followup } \\
\text { (years) }\end{array}$ & $\begin{array}{c}\text { Size of } \\
\text { endometrio- } \\
\text { sis } \\
\text { cohort } \\
\end{array}$ & $\begin{array}{l}\text { Ovarian cancer } \\
\text { cases identified } \\
\text { in the cohort }\end{array}$ & $\begin{array}{l}\text { Confounding factors } \\
\text { considered }\end{array}$ & Main limitations \\
\hline $\begin{array}{l}\text { Aris 2010, } \\
\text { Canada [17] }\end{array}$ & $\begin{array}{l}\text { Retrospective } \\
\text { cross-sectional }\end{array}$ & 9 & 2521 & 41 & $\begin{array}{l}\text { Age, pregnancies, family } \\
\text { history, race, oral } \\
\text { contraceptive, tubal } \\
\text { ligation, hysterectomy and } \\
\text { breastfeeding }\end{array}$ & $\begin{array}{l}\text { Retrospective collection of } \\
\text { data using a coded } \\
\text { computerised system. } \\
\text { Selection bias }\end{array}$ \\
\hline $\begin{array}{l}\text { Borgfeldt and } \\
\text { Andolf } 2004, \\
\text { Sweden. [18] }\end{array}$ & Case-control & 10 & 28,163 & 81 & Age and parity & \multirow{4}{*}{$\begin{array}{l}\text { Use of cohort of women } \\
\text { discharged from hospital with } \\
\text { a diagnosis of endometriosis. } \\
\text { This may lead to including } \\
\text { women with moderate and } \\
\text { severe endometriosis (hospital } \\
\text { stay patients) without } \\
\text { minimal and mild cases. This } \\
\text { may overestimate the risk } \\
\text { ratio. Selection bias. }\end{array}$} \\
\hline $\begin{array}{l}\text { Brinton et al. } \\
\text { 1997, Sweden. } \\
{[19]}\end{array}$ & $\begin{array}{l}\text { Retrospective } \\
\text { cohort study }\end{array}$ & 11.4 & 20,686 & 29 & $\begin{array}{l}\text { Age and length of history of } \\
\text { endometriosis }\end{array}$ & \\
\hline $\begin{array}{l}\text { Melin et al. } \\
\text { 2006, Sweden. } \\
{[20]}\end{array}$ & $\begin{array}{l}\text { Retrospective } \\
\text { cohort study }\end{array}$ & 12.7 & 64,492 & 122 & $\begin{array}{l}\text { Age and type of surgery } \\
\text { performed. }\end{array}$ & \\
\hline $\begin{array}{l}\text { Melin et al. } \\
\text { 2007, Sweden. } \\
{[21]}\end{array}$ & $\begin{array}{l}\text { Retrospective } \\
\text { cohort study }\end{array}$ & 13.4 & 63630 & 134 & $\begin{array}{l}\text { Age, parity, and type of } \\
\text { surgery performed }\end{array}$ & \\
\hline $\begin{array}{l}\text { Modugno et al. } \\
\text { 2004, USA. } \\
{[22]}\end{array}$ & Case-control & & & 177 & $\begin{array}{l}\text { Age, parity, oral } \\
\text { contraceptive use, tubal } \\
\text { ligation, family history of } \\
\text { ovarian cancer, and study } \\
\text { site, gynaecological surgical } \\
\text { procedures }\end{array}$ & $\begin{array}{l}\text { Recall and selection bias, as } \\
\text { the authors pooled data on the } \\
\text { history of endometriosis } \\
\text { reported by patients. }\end{array}$ \\
\hline $\begin{array}{l}\text { Ness et al. } \\
\text { 2000. USA. } \\
{[23]}\end{array}$ & Case-control & & & 66 & $\begin{array}{l}\text { Age, history of ovarian } \\
\text { cancer, parity, } \\
\text { breastfeeding, type and } \\
\text { length of each } \\
\text { contraceptive, tubal } \\
\text { ligation, hysterectomy, } \\
\text { ovarian operations. }\end{array}$ & $\begin{array}{l}\text { Data was collected by case } \\
\text { interviews. Recall bias. Low } \\
\text { participation rates among } \\
\text { cases and controls. }\end{array}$ \\
\hline $\begin{array}{l}\text { Olsen et al. } \\
\text { 2002, USA } \\
{[24]}\end{array}$ & $\begin{array}{l}\text { Prospective } \\
\text { cohort study. }\end{array}$ & 13 & 1,392 & 3 & $\begin{array}{l}\text { Age, education, marital } \\
\text { status, alcohol intake, } \\
\text { physical activity, smoking, } \\
\text { parity, oral contraceptive } \\
\text { use, HRT, history of } \\
\text { hysterectomy or dilatation } \\
\text { and curettage, BMI and } \\
\text { waist to hip ratio. }\end{array}$ & $\begin{array}{l}\text { Reliance on self-reports of } \\
\text { endometriosis in this cohort } \\
\text { (a questionnaire). Recall bias. } \\
\text { The number of women who } \\
\text { developed ovarian cancer is } \\
\text { quite limited. }\end{array}$ \\
\hline
\end{tabular}

endometrioid and/or clear-cell ovarian carcinoma as a specific histological subtype [27-34]. They all reported a specific link between endometriosis and endometrioid and/or clearcell ovarian carcinoma, with an OR ranging between 3.7 and 35.4 (CI 95\%). We have excluded these case series studies from our meta-analysis as there were not case-control or cohort studies.

In a previous review, Somigliana et al. included two other studies which assessed the risk of endometriosis on ovarian cancer in infertile patients [4]. In the first study, infertile patients with endometriosis had the highest risk with an SIR of 2.5 (95\% CI, 1.3-4.2) compared to the general population and an SIR of 4.2 (95\% CI, 2.0-7.7) for the group with primary infertility [15]. In the second study, endometriosis and unknown cause of infertility resulted in an independently associated elevation in ovarian cancer risk after adjustment for standard confounding factors (odds ratios (OR) 1.7 (95\% CI, 1.1-2.7) and 1.2 (95\% CI, 1.0 1.4), resp.,) [14]. As infertility involves multiple confounding factors, and to remove the selection bias in our review, these two studies were excluded from our review.

Additionally, we have excluded another study conducted by Kobayashi et al.'s in Japan. They documented only endometriomas and evaluated the risk of ovarian cancer based on varying time periods from time of diagnosis of endometrioma [16]. Kobayashi et al. study did not account for patients 
Forest plot to summarise the effect size (OR, SIR, RR) of the review studies

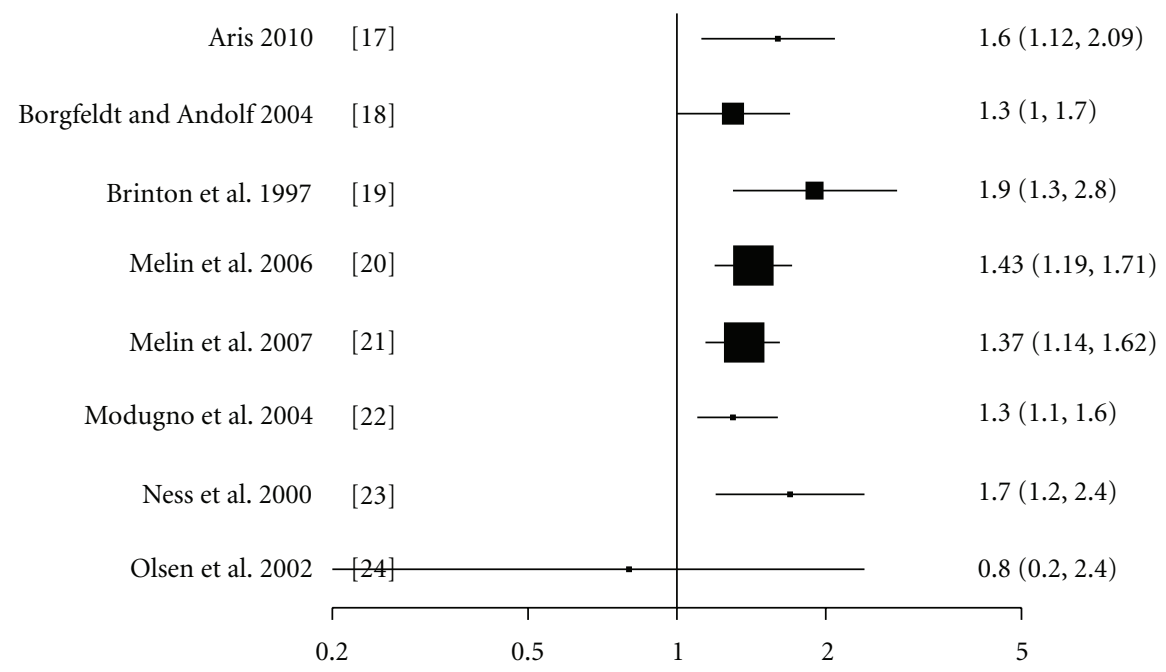

FIGURE 1: A Forest pilot summarises the eight studies' effect size. Effect size was measured in odd ratio (OR), standardized incidence ratio (SIR), or relative risk (RR). The 95\% confidence interval is represented by the horizontal line, and the dimensions of the boxes are proportional to the sample size.

with extraovarian endometriosis and only approximately one-third of these patients had surgically confirmed endometriomas, with the remaining diagnoses made based on ultrasonographic findings and physical exam only [16]. During followup of up to 17 years, 46 incidental ovarian cancers were identified, translating into a standardized incidence ratio of 8.95. This risk increased with age, with an incidence ratio of 13.2 in women over age 50 [16].

Many genetic, biological, and immunological studies have tried to address the causal relationship between endometriosis and ovarian cancer. Different types of genomic instability and mutations have been shown to occur in endometriosis and ovarian cancer $[35,36]$. Moreover, microsatellite analysis has demonstrated that loss of heterozygosity on p16 (Ink4), GALT (galactose-1-phosphate uridylyltransferase) and p53, as well as on APOA2 (apolipoprotein A), a region frequently lost in ovarian cancer, occurs in endometriosis [37]. Another study by Baxter et al. has found the GSTM1 (glutathione S-transferase M1) null allele not to be an endometriosis susceptibility allele [38]. However, it may predispose endometriotic lesions to malignant transformation to endometrioid and clear-cell ovarian cancer [38]. Overexpression of p53, oncogenic K-ras Pten deletion, and loss of heterozygosity may also be involved in the endometriosis transformation to ovarian cancer [39-41].

A vital factor in the development of both endometriosis and malignancy is considered to be angiogenesis. In a study by Hayrabedyan et al., the expression of several angiogenic factors (interleukin-1 alpha (IL-1 alpha), Fibroblast growth factor FGF-1, and S100A13) and a common pan-ovarian carcinoma antigen were investigated, in several cases of adenomyosis and ovarian endometriosis [42]. They have shown that the common ovarian carcinoma marker, as well as these angiogenic factors, was expressed in most of the studied cases, implying possible common pathological mechanisms shared between endometriosis and malignancy [42]. In another study, Chou et al. illustrated that the cyclooxygenase-2 (COX-2) overexpression rate was higher in ovarian carcinoma associated with endometriosis than in isolated ovarian carcinoma $(27.8 \%$ versus $5.6 \%, P=0.083)$ [43]. They suggested that COX-2 over-expression may be a result of the malignant transformation of endometriosis to endometrioid type ovarian cancer or may represent an interaction between the two cellular components [43]. By contrast, Keita et al. suggested alteration in the expression of interleukin-1 receptor antagonist IL-1RA, a key protector against tumorigenic effects of IL-1, as a possible link between the endometrium, endometriosis, and endometrioid ovarian cancer [44].

Recently, Wiegand et al. published new data implicating ARID1A (AT-rich interactive domain-containing protein 1A) as a tumor-suppressor gene frequently disrupted in ovarian clear-cell and endometrioid carcinomas [45]. They have found ARID1A mutations in 55 of 119 ovarian clear-cell carcinomas (46\%), 10 of 33 endometrioid carcinomas (30\%), and none of the 76 high-grade serous ovarian carcinomas [45]. They demonstrated that the loss of the BAF250a protein was correlated strongly with the ovarian clear-cell carcinoma and endometrioid carcinoma subtypes and the presence of ARID1A mutations [45]. By comparing ovarian clear-cell carcinomas to their contiguous atypical endometriotic lesions in two patients, they have shown that the same mutations 
may be present in the putative precursor lesions and in the tumors. In contrast, the distant endometriotic lesions do not have ARID1A mutations [45].

It seems, from the previous discussion, that there is insufficient evidence to suggest a specific gene mutation or a specific biological pathway that predisposes endometriosis patients to ovarian cancer. There is good evidence, however, to demonstrate the potential transformation from endometriosis to ovarian endometriosis cell and clear-cell carcinoma. The association between the two entities with an effect size of 1.32-1.9 may be due to sharing similar risk factors, rather than a causal relation.

\section{Conclusion}

There is increased risk of ovarian cancers, specifically endometrioid and clear-cell carcinoma, in women with endometriosis. The estimated effect size, however, is modest varying between 1.32 and 1.9. A causative relationship between the two incidences cannot be confirmed. However, there is increasing evidence on the role of genetic mutations in ovarian clear-cell and endometrioid carcinoma developing from endometriosis. There are few gene mutations involved, and yet more evidence is needed before generalising any mutation screening test or changing the treatment of endometriosis to include radical excision in case of a positive genetic mutation.

\section{References}

[1] Epidemiologyand aetiology of endometriosis, Annual Evidence Update(2009), Women's Health Specialist Library, 2010, http://www.library.nhs.uk/womenshealth/ViewResource.aspx? resID=307258.

[2] J. A. Sampson, "Endometrial carcinoma of the ovary arising in endometrial tissue in that organ," Archives of Surgery, vol. 10, pp. 1-72, 1925.

[3] R. B. Scott, "Malignant changes in endometriosis," Obstetrics and Gynecology, vol. 2, no. 3, pp. 283-289, 1953.

[4] E. Somigliana, P. Vigano', F. Parazzini, S. Stoppelli, E. Giambattista, and P. Vercellini, "Association between endometriosis and cancer: a comprehensive review and a critical analysis of clinical and epidemiological evidence," Gynecologic Oncology, vol. 101, no. 2, pp. 331-341, 2006.

[5] J. Akers, R. Aguiar-Ibáñez, A. Baba-Akbari Sari et al., Systematic Reviews: CRD's Guidance for Undertaking Reviews in Health Care, NHS Centre for Reviews and Dissemination, University of York, YorK, UK, 2009.

[6] C. B. Del Mar and P. P. Glasziou, 'Antibiotics for sore throat' (Cochrane review) in The Cochrane Library Issue 3, 1999 (Oxford) Glasgow appraisal tool, Systematic Review Study Group, http://ssrc.tums.ac.ir/SystematicReview/Glasgow.asp.

[7] R. B. Ness, "Endometriosis and ovarian cancer: thoughts on shared pathophysiology," American Journal of Obstetrics and Gynecology, vol. 189, no. 1, pp. 280-294, 2003.

[8] P. Vigano, E. Somigliana, F. Parazzini, and P. Vercellini, "Bias versus causality: interpreting recent evidence of association between endometriosis and ovarian cancer," Fertility and Sterility, vol. 88, no. 3, pp. 588-593, 2007.

[9] F. Nezhat, M. S. Datta, V. Hanson, T. Pejovic, C. Nezhat, and C. Nezhat, "The relationship of endometriosis and ovarian malignancy: a review," Fertility and Sterility, vol. 90, no. 5, pp. 1559-1570, 2008.

[10] A. Baldi, M. Campioni, and P. G. Signorile, "Endometriosis: pathogenesis, diagnosis, therapy and association with cancer (Review)," Oncology Reports, vol. 19, no. 4, pp. 843-846, 2008.

[11] N. F. Vlahos, K. P. Economopoulos, and S. Fotiou, "Endometriosis, in vitro fertilisation and the risk of gynaecological malignancies, including ovarian and breast cancer," Best Practice and Research: Clinical Obstetrics and Gynaecology, vol. 24, no. 1, pp. 39-50, 2010.

[12] H. Kobayashi, "Screening, epidemiology, molecular biology, and treatment strategies for endometriosis-associated ovarian cancer," Reproductive Medicine and Biology, vol. 9, no. 1, pp. 17-22, 2010.

[13] A. B. Hill, "The environment and disease: association or causation?" Proceedings of the Royal Society of Medicine, vol. 58, pp. 295-300, 1965.

[14] R. B. Ness, D. W. Cramer, M. T. Goodman et al., "Infertility, fertility drugs, and ovarian cancer: a pooled analysis of casecontrol studies," American Journal of Epidemiology, vol. 155, no. 3, pp. 217-224, 2002.

[15] L. A. Brinton, E. J. Lamb, K. S. Moghissi et al., "Ovarian cancer risk associated with varying causes of infertility," Fertility and Sterility, vol. 82, no. 2, pp. 405-414, 2004.

[16] H. Kobayashi, K. Sumimoto, N. Moniwa et al., "Risk of developing ovarian cancer among women with ovarian endometrioma: a cohort study in Shizuoka, Japan," International Journal of Gynecological Cancer, vol. 17, no. 1, pp. 37-43, 2007.

[17] A. Aris, "Endometriosis-associated ovarian cancer: a ten-year cohort study of women living in the Estrie Region of Quebec, Canada," Journal of Ovarian Research, vol. 3, no. 1, article no. 2, 2010.

[18] C. Borgfeldt and E. Andolf, "Cancer risk after hospital discharge diagnosis of benign ovarian cysts and endometriosis," Acta Obstetricia et Gynecologica Scandinavica, vol. 83, no. 4, pp. 395-400, 2004.

[19] L. A. Brinton, G. Gridley, I. Persson, J. Baron, and A. Bergqvist, "Cancer risk after a hospital discharge diagnosis of endometriosis," American Journal of Obstetrics \& Gynecology, vol. 177, no. 5, pp. 1274-1275, 1997.

[20] A. Melin, P. Sparen, I. Persson, and A. Bergqvist, "Endometriosis and the risk of cancer with special emphasis on ovarian cancer," Human Reproduction, vol. 21, no. 5, pp. 1237-1242, 2006.

[21] A. Melin, P. Sparén, and A. Bergqvist, "The risk of cancer and the role of parity among women with endometriosis," Human Reproduction, vol. 22, no. 11, pp. 3021-3026, 2007.

[22] F. Modugno, R. B. Ness, G. O. Allen, J. M. Schildkraut, F. G. Davis, and M. T. Goodman, "Oral contraceptive use, reproductive history, and risk of epithelial ovarian cancer in women with and without endometriosis," American Journal of Obstetrics and Gynecology, vol. 191, no. 3, pp. 733-740, 2004.

[23] R. B. Ness, J. A. Grisso, C. Cottreau et al., "Factors related to inflammation of the ovarian epithelium and risk of ovarian cancer," Epidemiology, vol. 11, no. 2, pp. 111-117, 2000.

[24] J. E. Olson, J. R. Cerhan, C. A. Janney, K. E. Anderson, C. M. Vachon, and T. A. Sellers, "Postmenopausal cancer risk after self-reported endometriosis diagnosis in the Iowa Women's Health Study," Cancer, vol. 94, no. 5, pp. 1612-1618, 2002.

[25] K. J. Rothman and C. Poole, "A strengthening programme for weak associations," International Journal of Epidemiology, vol. 17, no. 4, pp. 955-959, 1988. 
[26] L. A. Brinton, E. J. Lamb, K. S. Moghissi et al., "Ovarian cancer risk associated with varying causes of infertility," Fertility and Sterility, vol. 82, no. 2, pp. 405-414, 2004.

[27] P. Vercellini, F. Parazzini, G. Bolis et al., "Endometriosis and ovarian cancer," American Journal of Obstetrics and Gynecology, vol. 169, no. 1, pp. 181-182, 1993.

[28] E. Oral, S. Ilvan, E. Tustas et al., "Prevalence of endometriosis in malignant epithelial ovary tumours," European Journal of Obstetrics \& Gynecology and Reproductive Biology, vol. 109, pp. 97-101, 2003.

[29] R. Sainz De La Cuesta, J. H. Eichhorn, L. W. Rice, A. F. Fuller, N. Nikrui, and B. A. Goff, "Histologic transformation of benign endometriosis to early epithelial ovarian cancer," Gynecologic Oncology, vol. 60, no. 2, pp. 238-244, 1996.

[30] T. Toki and K. Nakayama, "Proliferative activity and genetic alterations in TP53 in endometriosis," Gynecologic and Obstetric Investigation, vol. 50, pp. 33-38, 2000.

[31] S. Ogawa, T. Kaku, S. Amada et al., "Ovarian endometriosis associated with ovarian carcinoma: a clinicopathological and immunohistochemical study," Gynecologic Oncology, vol. 77, no. 2, pp. 298-304, 2000.

[32] P. Vercellini, G. Scarfone, G. Bolis, G. Stellato, S. Carinelli, and P. G. Crosignani, "Site of origin of epithelial ovarian cancer: the endometriosis connection," British Journal of Obstetrics and Gynaecology, vol. 107, no. 9, pp. 1155-1157, 2000.

[33] H. Jimbo, H. Yoshikawa, T. Onda, T. Yasugi, A. Sakamoto, and Y. Taketani, "Prevalence of ovarian endometriosis in epithelial ovarian cancer," International Journal of Gynecology and Obstetrics, vol. 59, no. 3, pp. 245-250, 1997.

[34] M. Fukunaga, K. Nomura, E. Ishikawa, and S. Ushigome, "Ovarian atypical endometriosis: its close association with malignant epithelial tumours," Histopathology, vol. 30, no. 3, pp. 249-255, 1997.

[35] A. Fishman, D. Demirel, R. Laucirica et al., "Malignant tumors arising in endometriosis: clinical-pathological study and flow cytometry analysis," European Journal of Obstetrics Gynecology \& Reproductive Biology, vol. 70, no. 1, pp. 69-74, 1996.

[36] Y. Wu, Z. Basir, A. Kajdacsy-Balla et al., "Resolution of clonal origins for endometriotic lesions using laser capture microdissection and the human androgen receptor (HUMARA) assay," Fertility and Sterility, vol. 79, no. 3, pp. 710-717, 2003.

[37] A. G. Goumenou, D. A. Arvanitis, I. M. Matalliotakis, E. E. Koumantakis, and D. A. Spandidos, "Microsatellite DNA assays reveal an allelic imbalance in p16Ink4, GALT, p53, and APOA2 loci in patients with endometriosis," Fertility and Sterility, vol. 75, no. 1, pp. 160-165, 2001.

[38] S. W. Baxter, E. J. Thomas, and I. G. Campbell, "GSTM1 null polymorphism and susceptibility to endometriosis and ovarian cancer," Carcinogenesis, vol. 22, no. 1, pp. 63-65, 2001.

[39] R. Sainz De La Cuesta, M. Izquierdo, M. Canamero, J. J. Granizo, and F. Manzarbeitia, "Increased prevalence of p53 overexpression from typical endometriosis to atypical endometriosis and ovarian cancer associated with endometriosis," European Journal of Obstetrics \& Gynecology and Reproductive Biology, vol. 113, no. 1, pp. 87-93, 2004.

[40] D. M. Dinulescu, T. A. Ince, B. J. Quade, S. A. Shafer, D. Crowley, and T. Jacks, "Role of K-ras and Pten in the development of mouse models of endometriosis and endometrioid ovarian cancer," Nature Medicine, vol. 11, no. 1, pp. 63-70, 2005.

[41] A. H. Prowse, S. Manek, R. Varma et al., "Molecular genetic evidence that endometriosis is a precursor of ovarian cancer," International Journal of Cancer, vol. 119, no. 3, pp. 556-562, 2006.
[42] S. Hayrabedyan, M. Mourdjeva, S. Kyurkchiev, and I. Kehayov, "Immunofluorescent localization of Il- $1 \alpha$, FGF-1, S100A13 as angiogenic factors and a specific ovarian cancer marker (ovac) in endometriosis," Clinical Application of Immunology, vol. 3, no. 1, pp. 310-315, 2004.

[43] Y.-C. Chou, Y.-J. Chen, C.-R. Lai, P.-H. Wang, Hsin-Chan, and C.-C. Yuan, "Cyclooxygenase-2 expression is higher in ovarian cancer tissue adjacent to endometriosis than in ovarian cancer without comorbid endometriosis," European Journal of Obstetrics \& Gynecology and Reproductive Biology, vol. 124, no. 1, pp. 101-105, 2006.

[44] M. Keita, P. Bessette, M. Pelmus, Y. Ainmelk, and A. Aris, "Expression of interleukin-1 (IL-1) ligands system in the most common endometriosis-associated ovarian cancer subtypes," Journal of Ovarian Research, vol. 3, no. 1, pp. 1757-2215, 2010.

[45] K. C. Wiegand, S. P. Shah, O. M. Al-Agha et al., "ARID1A mutations in endometriosis-associated ovarian carcinomas," The New England Journal of Medicine, vol. 363, no. 16, pp. 1532-1543, 2010. 


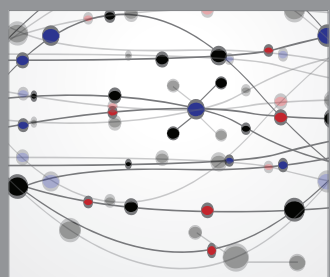

The Scientific World Journal
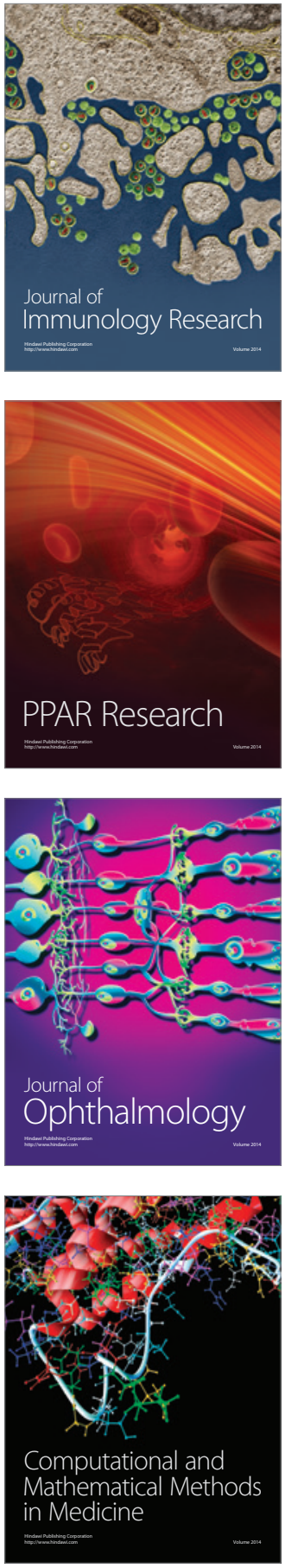

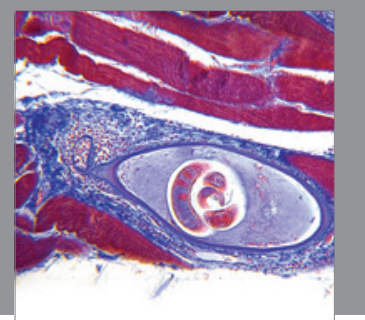

Gastroenterology

Research and Practice
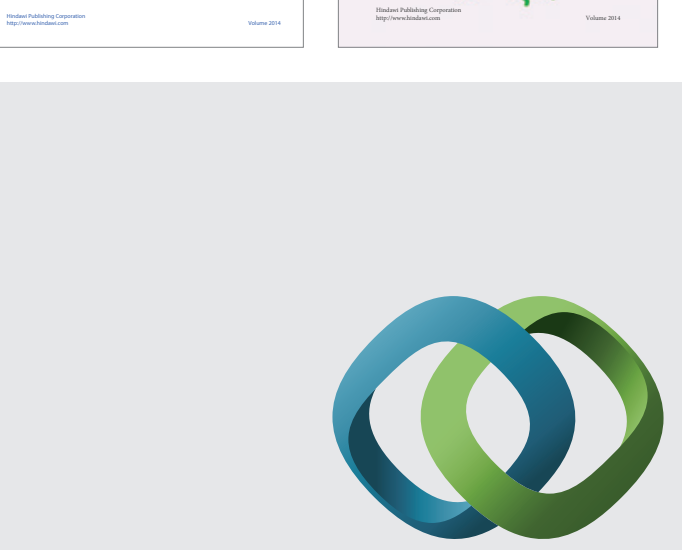

\section{Hindawi}

Submit your manuscripts at

http://www.hindawi.com
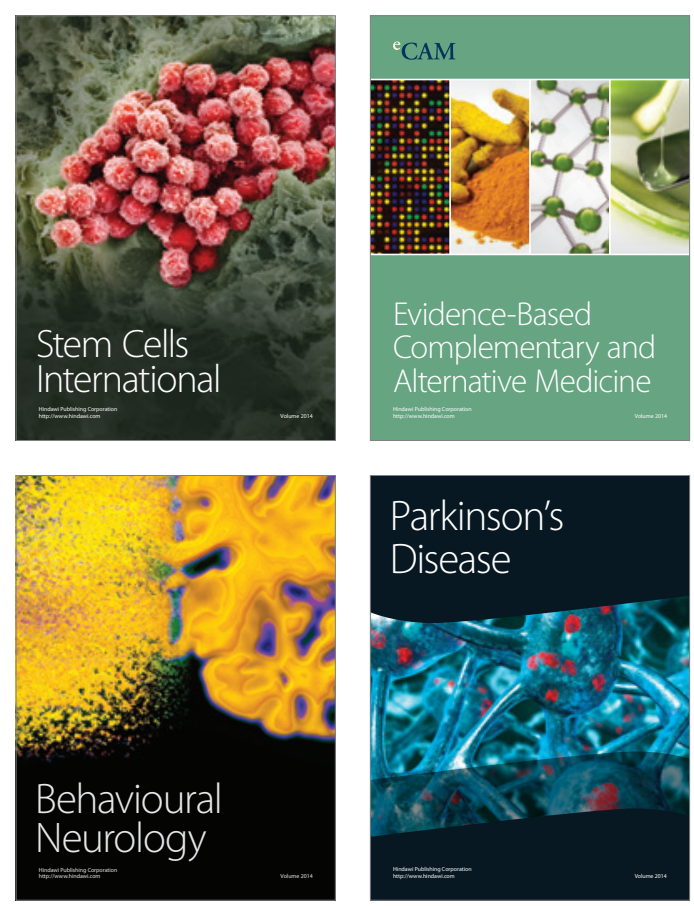

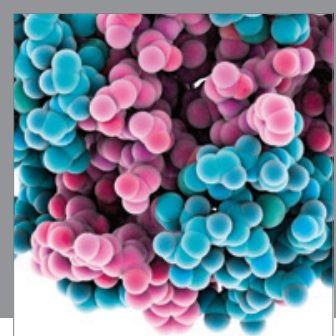

Journal of
Diabetes Research

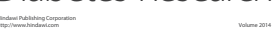

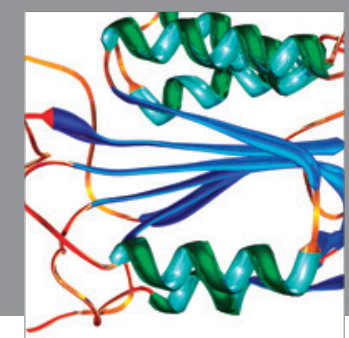

Disease Markers
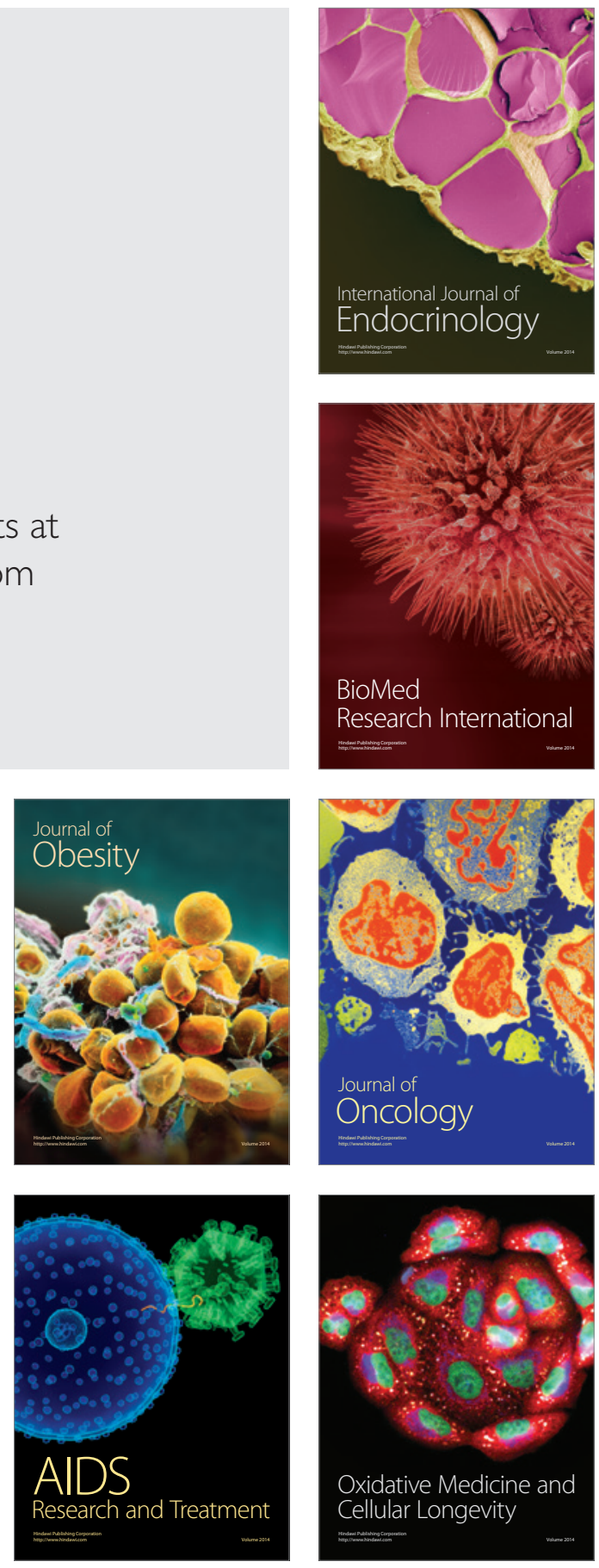